\title{
A review of several myopathy related to mitochondrial dysfunction
}

\author{
Wang Nan ${ }^{1,2}$, Oleksandr Motuziuk ${ }^{1}$, Dmytro Davydenko ${ }^{1}$ \\ 1 Lesya Ukrainka Volyn National University, Lutsk, Ukraine \\ 2 Jiangsu Medical Vocational College,Jiangsu,China \\ Correspondence: cmoplutsk@gmail.com
}

Отримано: 10.11.21; прийнято до друку: 24.12.21; опубліковано: 30.12.21

\begin{abstract}
The balance of protein production and consumption in muscles depends to a large extent on normal mitochondrial function. Mitochondrial dysfunction is inseparable from the occurrence of myopathy. This study explores the relationships between statin-induced myopathy, steroid myopathy, and skeletal muscle illness caused by alcohol addiction, as well as the relationship between these conditions and mitochondrial abnormalities.

Web of Science (WOS) central archive was analyzed for alcoholic myopathy research papers from 1999 to 2021, CiteSpace and WOS databases were used for evaluation the number of written articles, distribution of publications by region, research organizations, co-cited literature analysis, and keyword identification.

A total of 1,255 publications were collected after screening, with the number of published articles continually increasing. The annual average number of publications is 54.56 . Six countries publish the majority of the literature. The United States has published 383 papers in total, which places it first among all countries. It also has the most centrality, meaning that other countries value its scientific achievements more. There are 34 core authors and 238 papers published. Through cluster analysis, there are 9 categories that are significant clusters. Key words of co-occurrence research show that keywords such as nanoparticles, apoptosis, mitochondrial disorders, and inflammation are very common.
\end{abstract}

Key word: Citespace; alcoholic myopathy; statins and steroid; mitochondrial dysfunction;

\section{Аналіз міопатій, пов'язаних з мітохондріальною дисфункцією}

\author{
Ван Нань ${ }^{1,2}$, Олександр Мотузюк ${ }^{1}$, Дмитро Давиденко ${ }^{1}$ \\ 1 Волинський національний університет імені Лесі Украйнки, Луиьк, Украйна \\ 2 Медичний професійний коледж Цзян Су, Цзянсу, Китай \\ Адреса для листування: cmoplutsk@gmail.com
}

Анотація. Баланс синтезу і споживання білка в м'язах значною мірою залежить від нормальної функції мітохондрій. Мітохондріальна дисфункція невіддільна від виникнення міопатії. У цьому дослідженні аналізуються взаємозв'язки між міопатією, яка індукована статинами, стероїдною міопатією та захворюванням скелетних м'язів, спричиненим алкогольною залежністю, а також взаємозв'язок між цими станами та мітохондріальними аномаліями.

Центральний архів Web of Science (WOS) був проаналізований на предмет досліджень алкогольної міопатії з 1999 по 2021 рік, бази даних CiteSpace i WOS використовувалися для оцінки кількості написаних статей, розподілу публікацій за регіонами, дослідницьких організацій, аналізу спільно цитованої літератури та ідентифікація ключового слова.

Загалом, після аналізу було виділено 1255 публікацій, при цьому кількість опублікованих статей постійно збільшується. Середньорічна кількість публікацій - 54,56. Більшість літератури публікують шість країн. Загалом Сполучені Штати опублікували 383 статтей, що займає перше місце серед усіх країн. Вони також займають центральну позицію у цій сфері досліджень, тобто інші країни більше використовують їх наукові досягнення. Виділено 34 основних автори та 238 статей. За допомогою кластерного аналізу виділено 9 категорій, які є значущими кластерами. Ключові слова дослідження спільної появи показують, що такі ключові слова, як наночастинки, апоптоз, мітохондріальні порушення та запалення, $є$ дуже поширеними.

Ключові слова: Citespace; алкогольна міопатія; статини і стероїди; мітохондріальна дисфункція.

\section{INTRODUCTION}

Myopathy is usually a non-fatal muscle disease, the main clinical manifestations are skeletal muscle weakness, tenderness and pain. There are many reasons for myopathy, such as myopathy caused by statins, steroid myopathy, skeletal muscle disease caused by alcoholism, etc. ${ }^{1-6}$. Because alcoholism is also a risk factor for the other two myopathies, the pathophysiological mechanisms of these three myopathies must be 
investigated. In recent years, when people study the side effects of alcoholism, statins and steroid drugs on muscles, they will focus on the mechanisms of mTOR, IGF$1, \mathrm{Ca}^{2+}$, and mitochondrial biogenesis (HMG-COA) reductase inhibitors (ie statins) have muscle toxicity. Although relatively rare $(0,1 \%)$, they can cause serious muscle toxicity and complications. Muscle biopsy tends to mitochondrial dysfunction ${ }^{7}$. Alcoholic myopathy appears to be a common complication of alcoholism in approximately $50 \%$ of patients. In steroid myopathy, a significant reduction in glycogen phosphorylase activity has been observed, and this effect is more prominent in type II fibers ${ }^{8}$. When studying the above three myopathy, people either study the signal pathways related to protein synthesis and decomposition, or study whether there is excessive ROS (reactive oxygen species) formation. No matter which direction it is, it is vaguely pointing to the mitochondria. Mitochondrial homeostasis is maintained by mitochondrial biogenesis, mitochondrial fusion, fission and mitochondrial autophagy ${ }^{9}$. So are these myopathy all related to mitochondrial dysfunction, and can they all be treated with antioxidant therapies? This review, which employs CiteSpace as a methodology, focuses mostly on this topic.

This article analyzes articles related to myopathy treatment research in the Web of Science (WOS) core database in the United States from 1999 to 2021, and analyzes the overall development trend of the article, research institutions, authors, citations, keywords and emergent words. The purpose is to provide valuable information for the treatment of myopathy in the future.

\subsection{Data Sources}

The data comes from the US WOS database. This article uses the retrieval method of Chaomei Chene et $\mathrm{al}^{10,11}$. Keyword search 1: Subject: (myopath*) OR Subject: ("skeletal muscle diseases") OR Subject: ("muscle diseases"); Keyword 2: Subject: (glutathione) OR Subject: (glutathion) OR Subject: (glutathione hormone) OR subject: (1-glutathione) OR subject: (gluthathione) OR subject: (glutarates) OR subject: (acid glutathione) OR subject: (glutathione-s-transferase) AND document type: (Article OR Review); Search Keyword 3: Subject: (fullerene C60) OR Subject: (fullerene C70) OR Subject: (nanoparticles) OR Subject: (buckminster fullerene) OR Subject: (polyphenols); Search Keyword 4: Subject: (antirachitic factor) OR Subject: (vitamin d) AND Document Type: (Article OR Review); Keyword 5: Subject: (thiamine) OR Subject: (vitamin b1) AND Document Type: (Article OR Review); Keyword 6: Subject : (fertility vitamin) OR subject: (vitamin e) AND subject: (therapy) AND document type: (Article OR Review); search key 7: subject: (IGF-1) AND document type: (Article OR Review); Search Keyword 8: Subject: (alcohol*) OR Subject: (ethanol) AND Document Type: (Article OR Review); Search Keyword 9: Subject: (antioxidant NEAR/5 therapy) AND Document Type: (Article OR Review); Time span: 1985-2020, retrieval time is February 28, 2021. Search Keyword 10: Subject: ("nemaline myopathy") AND (therapy) AND Document Type: (Article OR Review); Search Keyword 11: Subject: ("Duchenne's muscular dystrophy") AND (therapy) AND Document Type: (Article OR Review); time span: 1985-2021, retrieval time is February 28, 2021.

Search strategy: Combine keyword 1 with 2, 3, 4, 5, 6, 7,8 , and 9 in an "AND" manner.

When Keyword 9 is combined with Keyword 1, there are only nine documents, so we use the citation report function of wos again ${ }^{11}$ to get 189 documents. In the end, this research obtained a total of 1807 documents.

1.2 Analysis methods, data inclusion, and exclusion criteria

CiteSpace was founded in 2004 by Dr. Chaomei Chen. This program can analyze data from the literature. The content that can be analyzed includes author, organization collaboration, keyword co-occurrence analysis, and emergency monitoring, which can help researchers in a specific field understand the evolution pattern of research topics, emerging hot spots and their period, important authors and institutions, and so on. As visual bibliometric applications, this software has been widely used in a number of scientific research fields. As a consequence, we selected this program for bibliometric analysis.

Literature inclusion criteria: (1)All literature related to myopathy; (2) The types of literature can be clinical case analysis, experimental research, theoretical discussion; (3) The types of literature resources are mainly journal articles, meta-analysis reviews and reviews. Exclusion criteria: (1)Repeated publications; (2)Documents whose full text is not available; 3) Documents mainly discussing Alzheimer's disease; (4)Documents whose main research object is liver disease.

1.3 Literature compilation and data analysis

Export the documents that meet the inclusion criteria in plain text format, and use R software to count the publication time of the documents; import the data into CiteSpace5.7.R2 software, and after deduplication processing, import the converted data into the software again. Set 1999-2021 as the analysis time (because the system defaults to mark the data of the unpublished year as 1999), select the author, institution, citation, and keywords as the node type, and draw the corresponding visual knowledge graphs respectively for the myopathy author, cooperation with institutions, citing article analysis, and keyword co-occurrence, clustering and emergence analysis. Each visualized knowledge map employs a 1-year partition process, as does the keyword knowledge map. The top 50 things are chosen, rated from high to low frequency, i.e., Top $\mathrm{N}$ per slice is 50, and the cutting method is Pathfinder, Pruningsliced networks, and Pruning the combined network.

\section{RESULT}

2.1 Analysis of publication year

From 1999 to 2021, 1807 articles related to myopathy were published. Because our search time was February 28, 2021, only 6 articles were retrieved in 2021. From 1999 to 2021, the number of publications in this area increased in a phased manner. Prior to 2009, the rate of publication growth was sluggish. Since 2010, the number of publications in this sector has almost steadily 
increased year after year. The amount of articles published before 2009 accounted for $25.70 \%$ of the total amount of articles published, and the amount of articles published in the past 5 years accounted for $43.66 \%$ of the total. It can be seen that the research on myopathy is getting more and more attention. Overall, the average number of posts is 56.77. Use $\mathrm{R}$ "forecast" package for data processing. Use Holt's exponential smoothing to fit the time series with horizontal terms and trend terms (slope), and take the log value of the number of posts. The formula is $\mathrm{Yt}=$ level+slope*t+irregulart. We get Figure 1 and Table 1 . There will be about 202 articles published in 2021, with a $95 \%$ confidence interval of [154.9020, 264.3448].

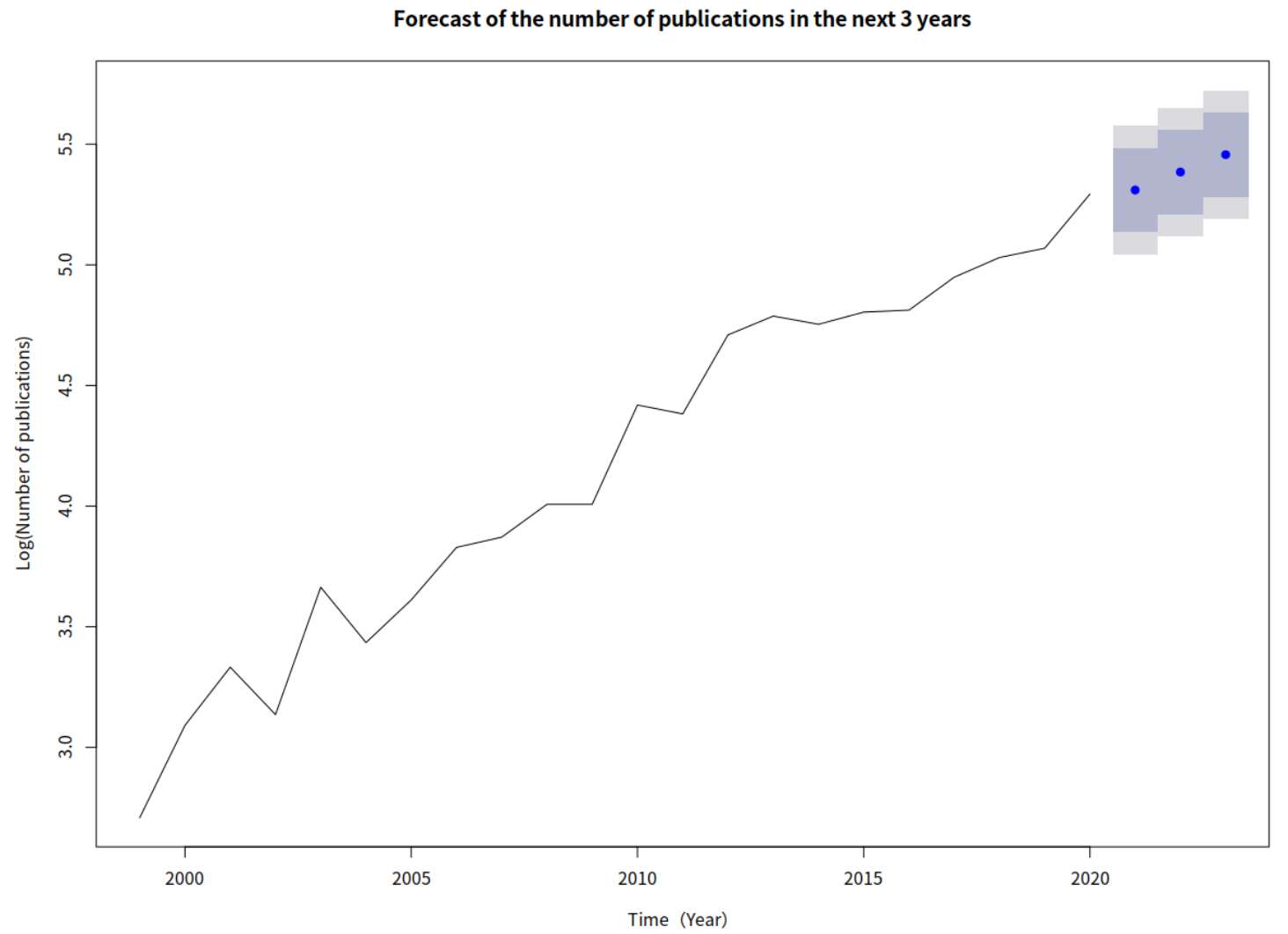

Figure 1. Forecast of the number of publication in the next 3 years

The $\mathrm{X}$ axis is the time of publication of the literature, and the $\mathrm{Y}$ axis is the Log value of the number of publications; this figure predicts the number of publications related to myopathy in the next 3 years starting from 2021. The specific values are shown in Table 1 .

Various data of the predicted value of the number of documents in the next 3 years

Table 1

\begin{tabular}{|c|c|c|c|c|c|}
\hline & Mean & Low 80 \% & Low 95 \% & High 80 \% & High 95 \% \\
\hline 2021 & 202.3550 & 169.9137 & 154.9020 & 240.9902 & 264.3448 \\
\hline 2022 & 218.0333 & 183.0785 & 166.9037 & 259.6620 & 284.8261 \\
\hline 2023 & 234.3472 & 196.7770 & 179.3919 & 279.0907 & 306.1377 \\
\hline
\end{tabular}

Mean: mean; Low $80 \%$ : lower limit of $80 \%$ confidence interval; High $80 \%$ : upper limit of $80 \%$ confidence interval; Low $90 \%$ : lower limit of $90 \%$ confidence interval; High $90 \%$ : upper limit of $90 \%$ confidence interval.

2.2 Regional distribution of high-volume publications from 1999 to 2021

According to the countries and regions where 1807 papers were written, the United States published the most (383), followed by the United Kingdom (123), Italy (109), China (105), France (98), and Germany (91). See Table 2 and Figure 2 for more details. There is a purple band in the outermost circle of the nodes in the
United States, the United Kingdom, Germany, France, Spain, and Canada, showing that these countries' research is central, and their research findings are more noticed by other countries. The United States produces a large number of papers. The color of the nodes shows that myopathy study in the United States has strong consistency, and the centrality is also the strongest $(0.57)$. 


\section{PEOPLES R CHINA}

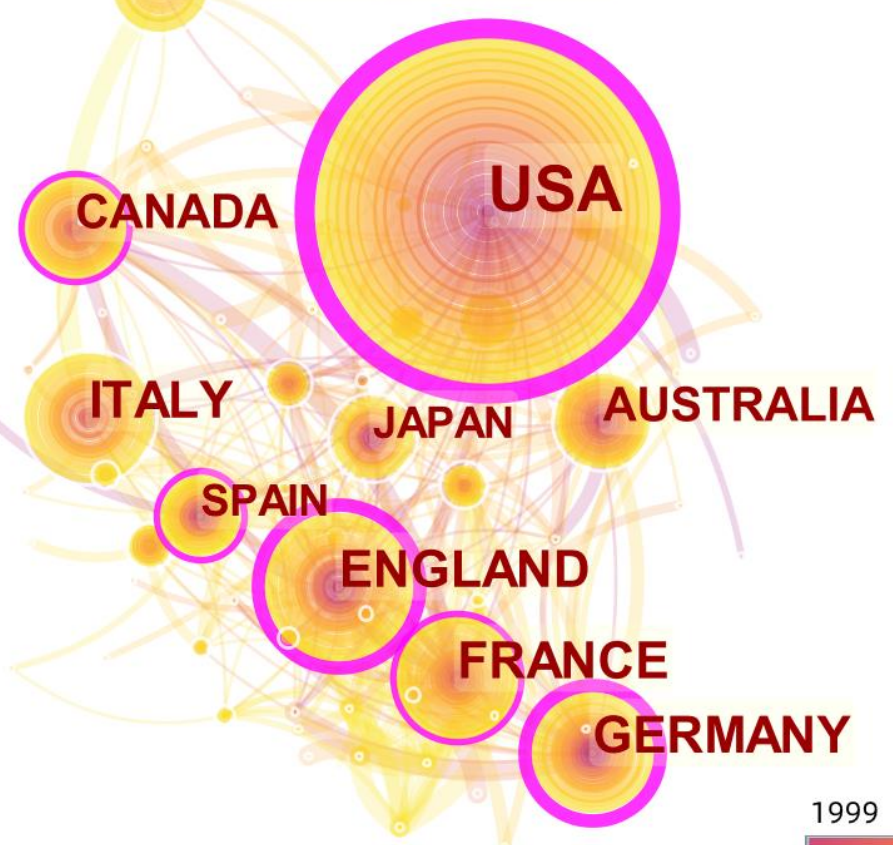

1999

Figure 2. Distribution of relevant literature publication countries from 1999 to 2021

Table 2

High publication volume of literature on myopathy from 1999 to 2021 Regional distribution (the top 6 regions in terms of post volume)

\begin{tabular}{|c|c|c|c|}
\hline Rank & country / region & Amount of papers/articles & centrality \\
\hline 1 & USA & 383 & 0.57 \\
\hline 2 & ENGLAND & 123 & 0.30 \\
\hline 3 & ITALY & 109 & 0.09 \\
\hline 4 & CHINA & 105 & 0.01 \\
\hline 5 & FRANCE & 98 & 0.12 \\
\hline 6 & GERMANY & 91 & 0.21 \\
\hline
\end{tabular}

\subsection{Distribution of research institutions}

Set the network node to "Institution" to generate a network map of research institutions. The top 10 research institutions with publication volume are located in the United States, France, the United Kingdom, Australia and other countries. Kings College London published 31 journals, accounting for $20.9 \%$ of articles published by the top ten institutions. In recent years, the institution has focused on experimental therapies for myopathy ${ }^{12}$. The next most productive institutions are INSERM, accounting for $13.50 \%$, and Harvard Univ, accounting for $10.13 \%$. See Table 3 . In particular, in the field of myopathy, Kings College London and Harvard University collaborated in $2006^{13}$. This research expands on the anti-oxidative damage mechanism of alcohol-induced skeletal myopathy and provides a theoretical foundation for myopathy antioxidant treatment. In terms of centrality, the centrality value of Kings Coll London is 0.11 , which is twice that of the second place, which fully demonstrates the institution's recognition in myopathy research. Overall, there is a limited network of cooperation among the top 10 institutions.

Table 3

High publication volume of literature on alcoholic myopathy from 1999 to 2021 Institution distribution (the top 10 institutions in terms of post volume)

\begin{tabular}{|c|l|c|c|}
\hline Rank & \multicolumn{1}{|c|}{ institution } & Amount of papers/articles & centrality \\
\hline $\mathbf{1}$ & \multicolumn{1}{|c|}{$\mathbf{3}$} & $\mathbf{4}$ \\
\hline 1 & Kings Coll London & 31 & 0.11 \\
\hline 2 & INSERM & 20 & 0.05 \\
\hline 3 & Harvard Univ & 15 & 0.06 \\
\hline 4 & McMaster Univ & 14 & 0.04 \\
\hline 5 & CNRS & 14 & 0.02 \\
\hline 6 & Kobe Univ & 11 & 0.01 \\
\hline 7 & Penn State Univ & 11 & 0.01 \\
\hline
\end{tabular}


The end of the table 3

\begin{tabular}{|c|l|c|c|}
\hline $\mathbf{1}$ & \multicolumn{1}{|c|}{$\mathbf{2}$} & $\mathbf{3}$ & $\mathbf{4}$ \\
\hline 8 & Univ Barcelona & 11 & 0.00 \\
\hline 9 & Emory Univ & 11 & 0.00 \\
\hline 10 & Univ Western Australia & 10 & 0.08 \\
\hline
\end{tabular}

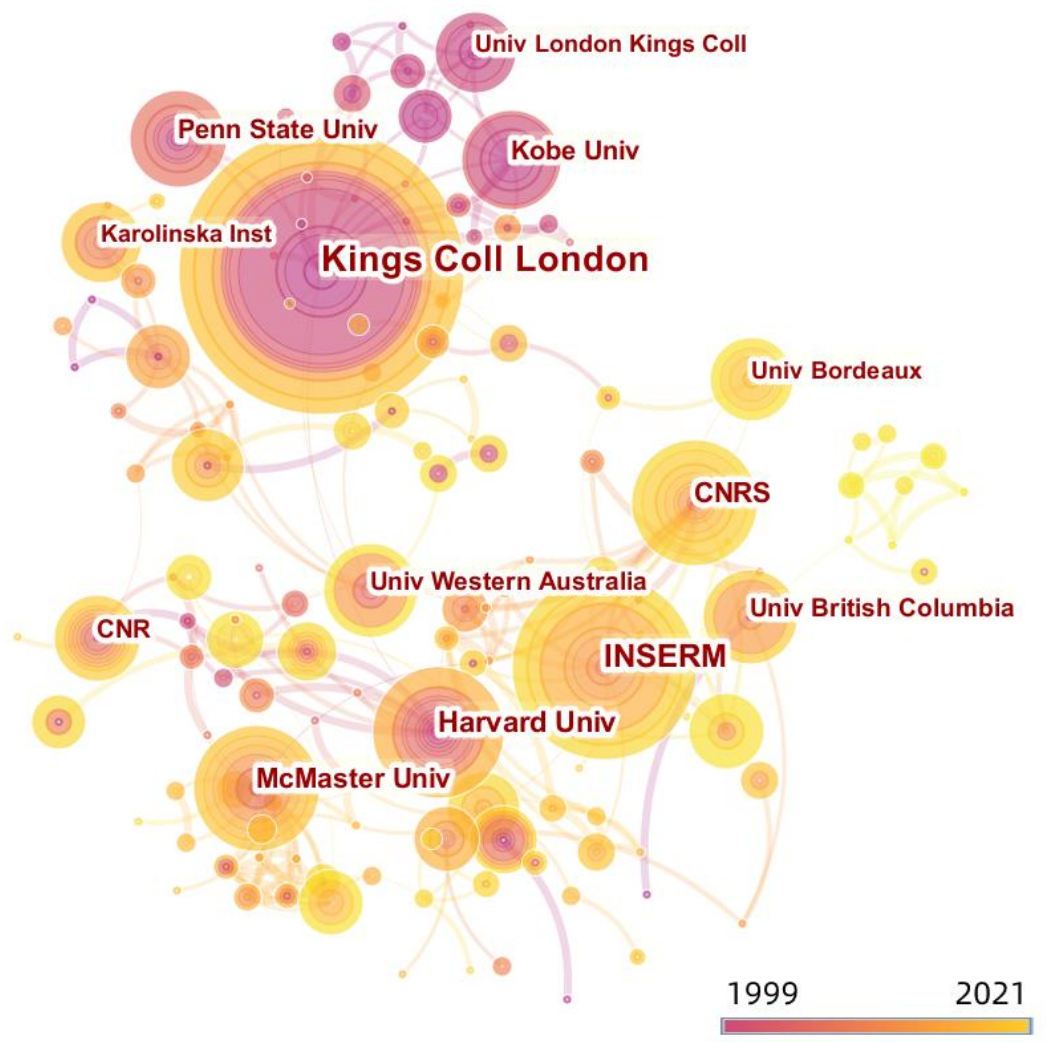

Figure 3. Distribution of relevant literature publication institution from 1999 to 2021

2.4 Analysis of Knowledge Graph of Document Authors' Cooperation Network

With the authors of the literature as the network node, the author's cooperation in the past 23 years is generated through software, as shown in Figure 4. The graph consists of 726 nodes and 825 links. The size of the nodes in the graph represents the amount of articles published by authors, the links between nodes represent cooperation between authors, and the thickness of the links represents the degree of cooperation. VR PREEDY, CHARLES H LANG, and J FERNANDEZSOLA et al. ${ }^{14-16}$ specifically research alcoholic myopathy, investigating the pathogenic mechanism and treatment strategies. Authors with Nowak and Nigel G LAIN as the core have mainly studied the pathogenic mechanism and application of alpha-actin protein or its gene in skeletal myopathy in recent years ${ }^{17}$. KATASHI OKOSHI, Gomes and others ${ }^{18}$ mainly study the theory and application of antioxidant therapy in skeletal myopathy. According to Price's Law (ZONG Shuping 2016), calculate whether the target author is the core

author, and the calculation formula is $\mathrm{N}=0.749 * \sqrt{n_{\text {pmax }}}$, the number of papers published by the authors who published the most papers during the statistical era is referred to as $n_{\text {pmax }}$. Calculate the value of $\mathrm{N}$, as long as the number of papers written is greater than N. These authors are referred to as core authors. The maximum number of papers involved in this study is 27 , and $\mathrm{N}=3.892$ can be calculated by the formula. Therefore, in this study, authors with $\geq 4$ papers are the core authors. There are 34 core authors, and the total number of published papers is 238 , accounting for $18.96 \%$ of the total number of included documents.

\subsection{Co-cited literature analysis}

The co-citation cluster analysis of a document can objectively reflect the degree of recognition of the document by academia. While doing citation analysis, you can also perform cluster analysis to find research hotspots and trends. Therefore, in order to further analyze the current status of myopathy research, this study conducted an in-depth analysis of the highly cited documents and the highly cited documents involved in each cluster. Through cluster analysis, meaningful and significant clusters are divided into 9 categories, as shown in Table 4. Use the software to analyze the document cocitation and obtain a visual map with $\mathrm{N}=1052$ and $\mathrm{E}=$ 2625 (Figure 5). The most representative article in the label \#0 cluster is the article published by Preedy et al. on EUROPEAN JOURNAL OF NEUROLOGY ${ }^{19}$. The most representative of the label \#1 cluster is the article 
by Laufs et al. on treatment options for statin-associated muscle symptoms ${ }^{20}$. Another example is the label \#20 cluster represented by Gomes ${ }^{21}$. The research group mainly studies the role of oxidative stress in the formation of skeletal myopathy.

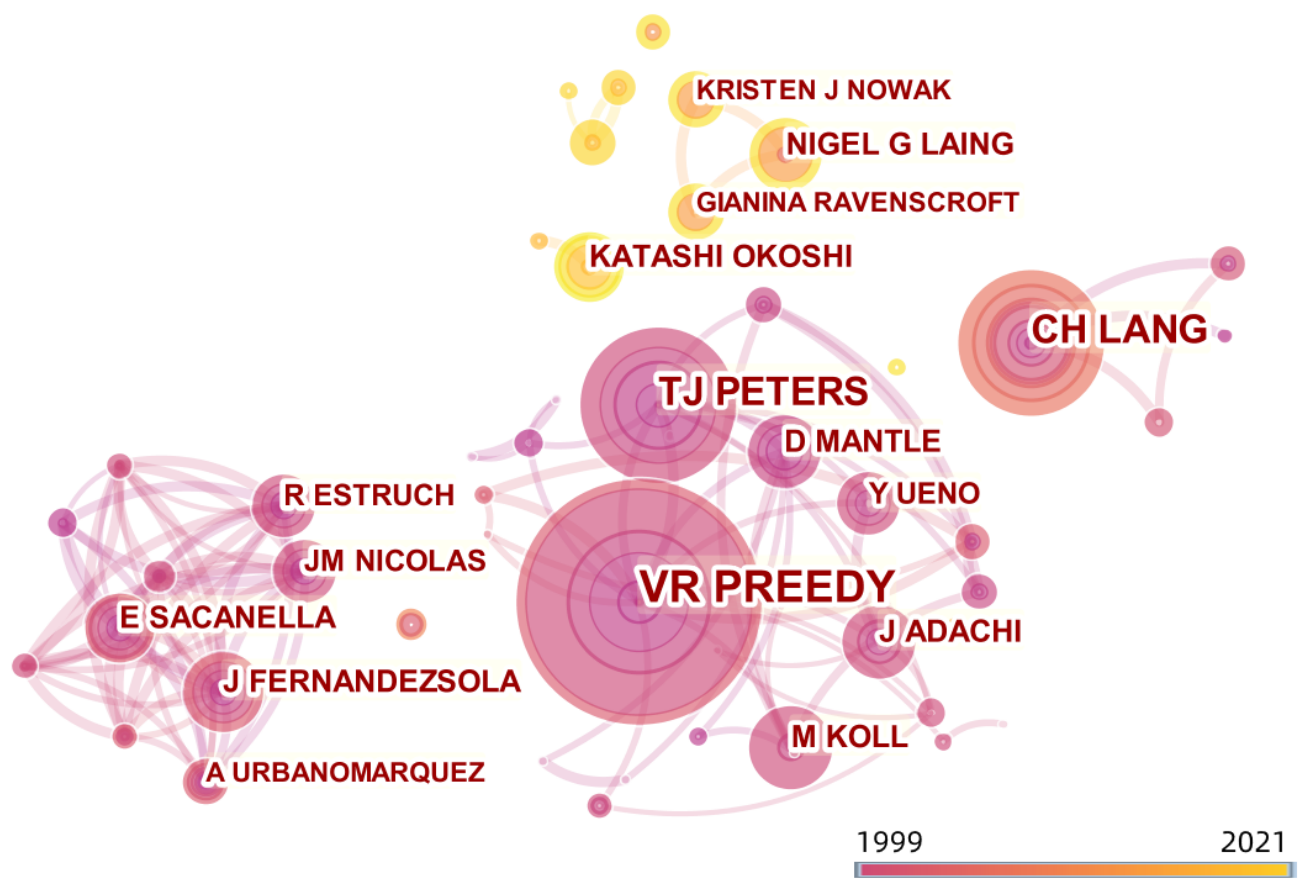

Figure 4. Knowledge Atlas of Collaborative Network of Authors from 2000 to 2020
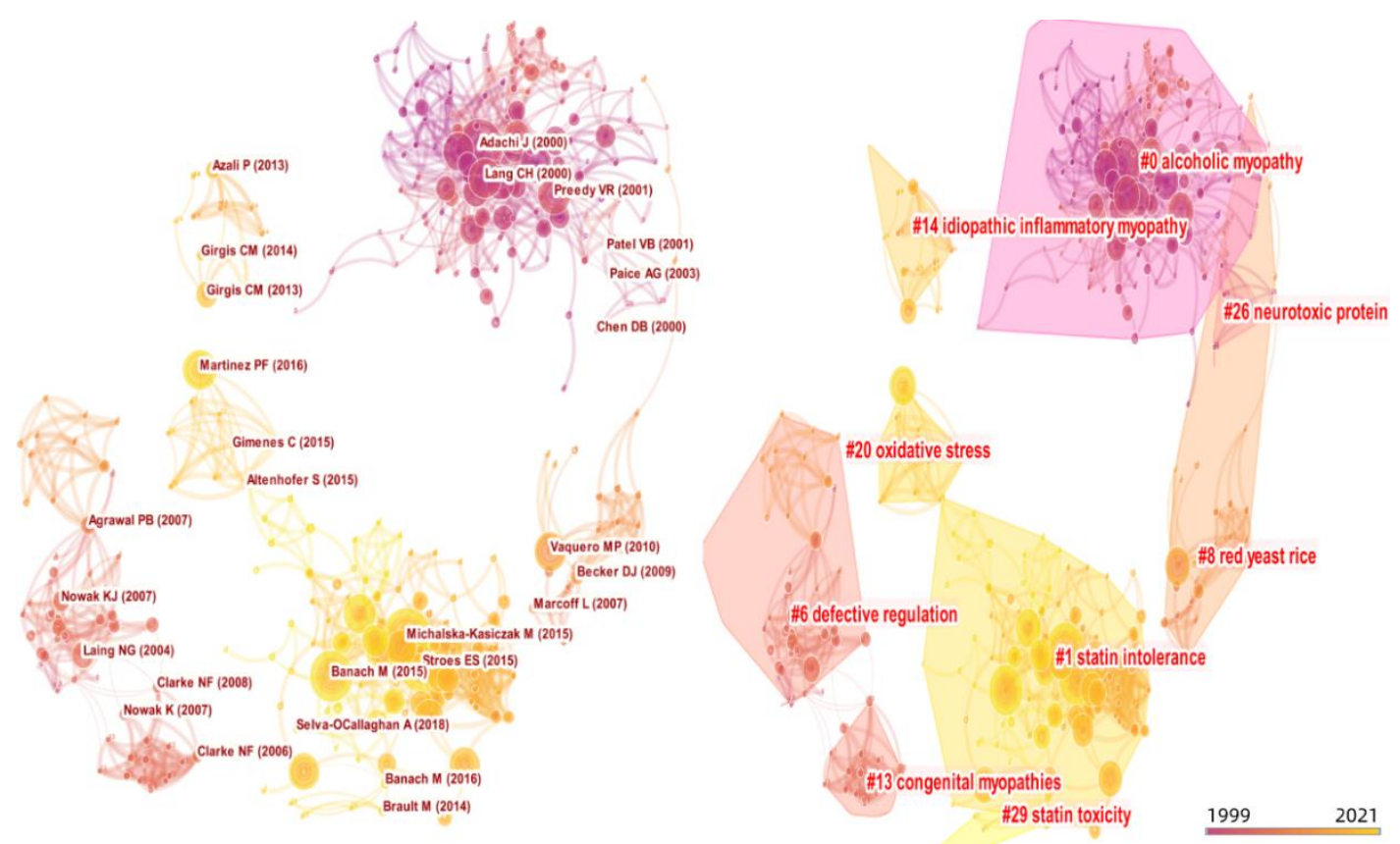

Figure 5. Co-cited and clustering map of articles in the field of alcoholic myopathy from 1999 to 2021

Major clusters of co-cited references

Table 4

\begin{tabular}{|l|l|c|l|}
\hline ID & \multicolumn{1}{|c|}{ SilhouettE } & Year & \multicolumn{1}{c|}{ Cluster Label(LLR) } \\
\hline $\mathbf{1}$ & $\mathbf{2}$ & $\mathbf{3}$ & $\mathbf{4}$ \\
\hline 0 & 0.973 & 1999 & alcohol-induced muscle disease; ethanol treatment \\
\hline 1 & 0.986 & 2014 & statin intolerance; treatment option \\
\hline 6 & 0.963 & 2005 & defective regulation; skeletal myopathies \\
\hline 8 & 0.995 & 2009 & red yeast rice \\
\hline
\end{tabular}


The end of the table 4

\begin{tabular}{|l|l|l|l|}
\hline $\mathbf{1}$ & \multicolumn{1}{|c|}{$\mathbf{2}$} & $\mathbf{3}$ & \multicolumn{1}{c|}{$\mathbf{4}$} \\
\hline 13 & 0.966 & 2006 & congenital myopathies \\
\hline 14 & 1 & 2012 & idiopathic inflammatory myopathy \\
\hline 20 & 1 & 2015 & oxidative stress \\
\hline 26 & 0.992 & 2000 & neurotoxic protein \\
\hline 29 & 0.983 & 2016 & statin toxicity \\
\hline
\end{tabular}

2.6 keywords visualization and analysis

In this study, the keyword co-occurrence and highlighted word map were obtained through the analysis of CiteSpace software (Figure 6, 7, 8). Through keyword co-occurrence analysis, the hot keywords in the field of myopathy from 1999 to 2020 are myopathy, oxidative stress, vitamin d, vitamin d deficiency, mitochondrial myopathy, alcoholic myopathy, antioxidant therapy, statin, therapy, glutathione, nanoparticle, vitamin e, coenzyme q10, IGF-1 and other high-frequency keywords. From the analysis of keyword time zone and highlighted word map, it can be concluded that the new keywords in the past 5 years are nanoparticle (2016-2021), autophagy (2017-2021), dysfunction (2017-2019), activation (2016-2019), imflammation (2018-2021), mitochondrial dysfunction (2019-2021). And the highlighting word map analysis can show that the popularity of keywords such as nanoparticle, autophagy, and mitochondrial dysfunction will continue until 2021, Figure 9. The label of the largest node in the middle is myopathy, which contains various types of myopathy, such as myopathy caused by alcoholism ${ }^{22}$, The relationship between vitamin $\mathrm{D}$ and myopathy ${ }^{23}$, myopathy caused by statins $^{24}$. The node corticosteroid represents myopathy caused by steroid hormones ${ }^{25}$ (Figure 6, 8). The node ethanol represents the research of alcoholic

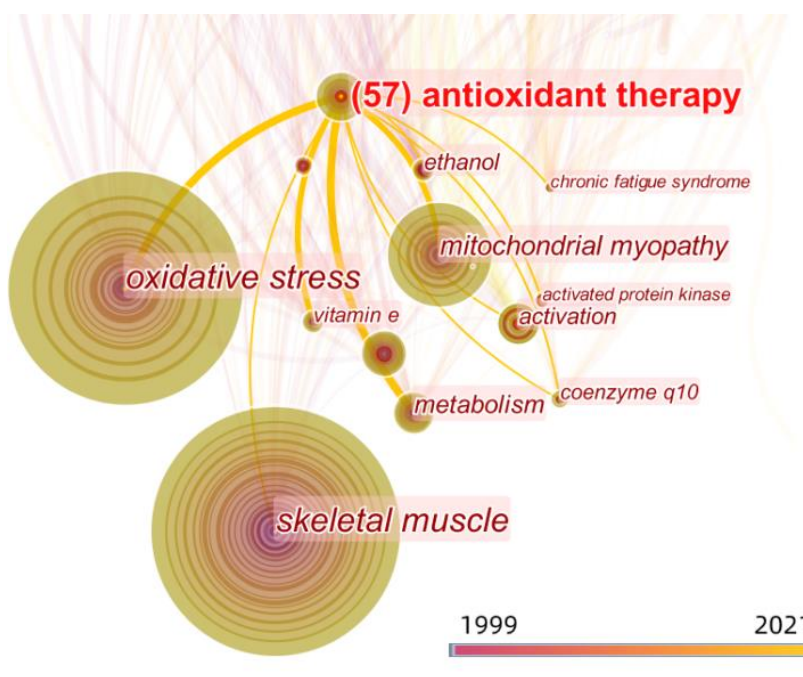

Figure 6. Visualization diagram of the relationship between antioxidant therapy in each keyword node myopathy. At the same time, it can be discovered from the connection relationship between the nodes that alcoholic myopathy can be treated with antioxidant therapy(Figure 6). In addition, we can also see that vitamin e and coenzyme q10 are a kind of antioxidant therapy. In the network diagram of another node therapy (Figure 7 ), we can find that nanoparticle is one of many ways to treat myopathy. From the graph of the network nodes in Figure 8, we can see that corticosteroid is directly or indirectly related to coenzyme Q10 and mitochondrial dysfunction. It can be seen from Figure 9 that the most intense and hottest highlight keywords are nanoparticle and mitochondrial dysfunction. The study included in mitochondrial dysfunction by Moacir Wajner et al. ${ }^{26}$ revealed that fatty acid accumulation can interfere with energy balance in the mitochondria, inhibit oxidative phosphorylation, decrease ATP synthesis, and increase free radical output. Nanoparticles can be used in many different fields. For example, fullerene C60 is a free radical scavenger with better performance ${ }^{27}$. Nanoparticles are foreign to the human body, similar to bacteria, viruses, parasites, and can stimulate cells to produce autoph$\mathrm{agy}^{28}$. In general, nanoparticles can play a protective antioxidant role in the body, and autophagy produced by nanoparticles can also remove oxidative stress $^{29}$.

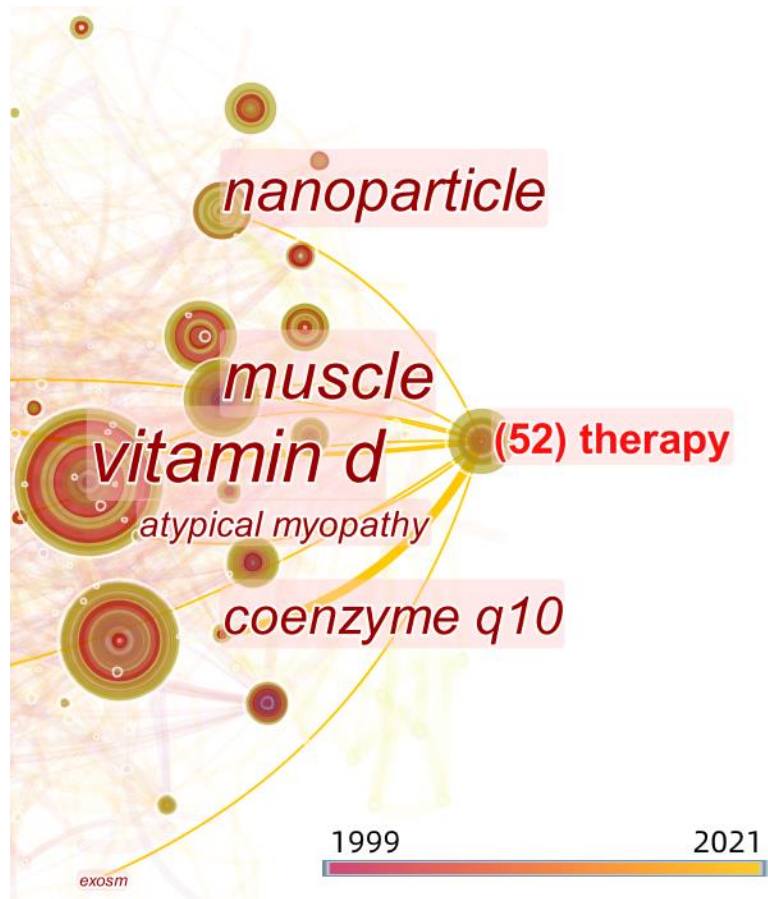

Figure 7. Visualization of the main treatment methods of myopathy 


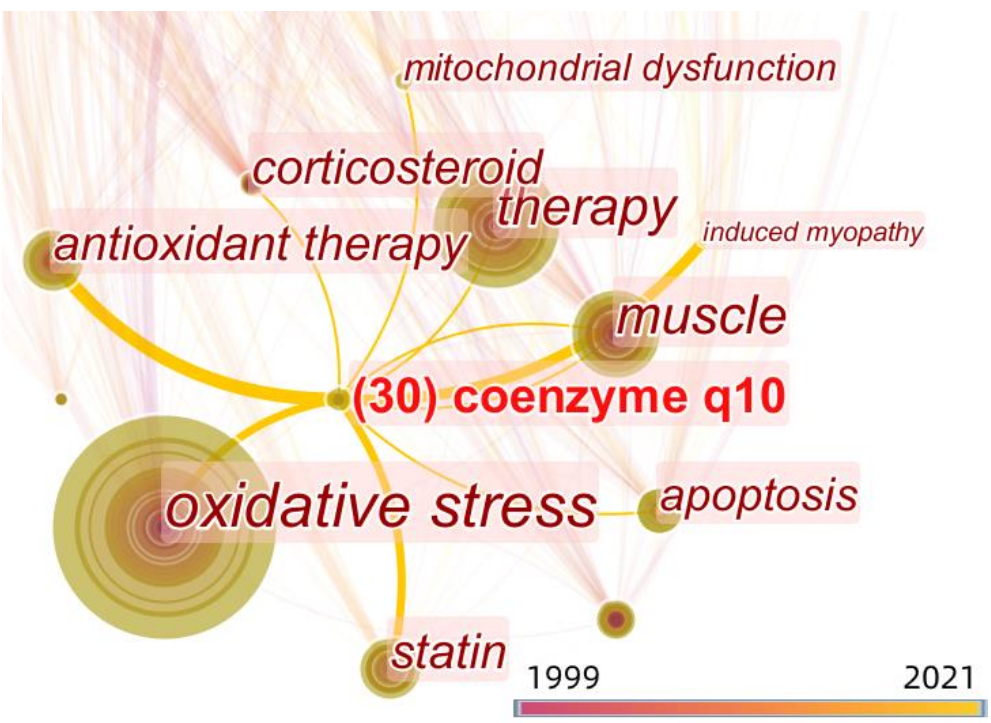

Figure 8. Visualization of the commonality of the pathogenesis of the three myopathy

\section{Top 20 Keywords with the Strongest Citation Bursts}

\begin{tabular}{llrll}
\multicolumn{1}{c}{ Keywords } & \multicolumn{3}{c}{ Year Strength Begin } & End \\
myopathy & 1999 & 10.56 & $\mathbf{1 9 9 9}$ & 2007 \\
rat & 1999 & 8.16 & $\mathbf{1 9 9 9}$ & 2003 \\
ethanol & 1999 & 7.81 & $\mathbf{1 9 9 9}$ & 2005 \\
tissue & 1999 & 4.89 & $\mathbf{1 9 9 9}$ & 2002 \\
alcoholic myopathy & 1999 & 15.16 & $\mathbf{2 0 0 0}$ & 2007 \\
protein synthesis & 1999 & 8.67 & $\mathbf{2 0 0 0}$ & 2008 \\
lipid peroxidation & 1999 & 6.15 & $\mathbf{2 0 0 0}$ & 2005 \\
acetaldehyde & 1999 & 7.41 & $\mathbf{2 0 0 1}$ & 2005 \\
vitamin d deficiency & 1999 & 7.13 & $\mathbf{2 0 0 8}$ & 2014 \\
prevalence & 1999 & 5.31 & $\mathbf{2 0 0 9}$ & 2013 \\
macrophagic myofasciti & 1999 & 5.85 & $\mathbf{2 0 1 1}$ & 2013 \\
nanoparticle & 1999 & 10.89 & $\mathbf{2 0 1 6}$ & 2021 \\
activation & 1999 & 4.94 & $\mathbf{2 0 1 6}$ & 2019 \\
autophagy & 1999 & 10.87 & $\mathbf{2 0 1 7}$ & 2021 \\
in vitro & 1999 & 8.15 & $\mathbf{2 0 1 7}$ & 2021 \\
dysfunction & 1999 & 6.77 & $\mathbf{2 0 1 7}$ & 2019 \\
apoptosis & 1999 & 6.38 & $\mathbf{2 0 1 7}$ & 2021 \\
mouse model & 1999 & 7.38 & $\mathbf{2 0 1 8}$ & 2021 \\
inflammation & 1999 & 5.44 & $\mathbf{2 0 1 8}$ & 2021 \\
mitochondrial dysfunction & 1999 & 5.33 & $\mathbf{2 0 1 9}$ & 2021 \\
\hline & & & 2005 \\
\hline
\end{tabular}

Figure 9. Annual ranking of keywords with the strongest citation bursts related to

\section{DISCUSSION}

Myopathy has been on the rise in recent years, with the disease becoming more common with each passing year. Myopathy has attracted more attention because to its increasing prevalence and the numerous damage it causes to people's bodies and minds. This work analyzes the literature on myopathy in the WOS database using bibliometrics and discovers that the number of literature publications has a wave-like increase tendency over time, indicating that research is increasing rapidly and people are paying more and more attention to it. In terms of research countries and areas, the United States has published more publications in this field than other countries (regions) and has done a significant amount of work in the subject of myopathy research. However, in Europe, there are more countries (regions) involved in myopathy research.

We can observe from the term emergence map that numerous new study directions have arisen in the last three years. Some hot keywords have a high intensity, such as nanoparticle (10.89), while others have a low intensity, such as mitochondrial dysfunction (5.33), yet this term is a new hot area that has emerged in the last two years. The explanation for the low intensity could be that we only found 18 references in the 2021 literature. Many new study topics have appeared in the last ten years, such as "autophagy," which has been a 
research hotspot from 2017 to 2021, with an outbreak value of 10.87 . However, the term "mitochondrial dysfunction" first appeared in 2019. Although the new research direction has a low burst value, it is 5.3. However, it is possible that this direction may become the next research hotspot in the future.

Under normal conditions, mitochondrial homeostasis is dependent on a number of activities, including biogenesis, fusion, and fission. Any disruption to these processes will result in mitochondrial malfunction. Alcohol-fed rats have higher acetaldehyde levels in their mitochondria, which disrupts the electron transport complex (CI-IV), resulting in an excess of reactive oxygen species $(\mathrm{ROS})^{30}$. In addition, long-term use of corticosteroid drugs can also induce excessive production of reactive oxygen species (ROS), leading to mitochondrial dysfunction and apoptosis in myogenic cells ${ }^{25}$. Statins can also impair the mitochondrial respiratory chain's activity, lowering ATP and boosting ROS generation ${ }^{31}$. The three reasons described above can cause an increase in the concentration of ROS in the body. Of course, because the concentration of ROS has increased, "nanoparticle" can be employed to reduce the concentration of ROS. Figure 9 also shows that "nanoparticle" has been a popular study topic since 2016 .

\section{SUMMARY}

It is expected that the study focus of these three myopathies will shift to a more in-depth investigation of the mechanism of mitochondrial malfunction in the next years. Of course, future research hotspots are not restricted to this. For example, the creation of nanoparticle therapeutics for myopathy and the investigation of myopathy's autophagy process have been research hotspots in recent years, and they may continue to be so in the future.

\section{REFERENCES}

1. Kim, K., Anderson, E. M., Scali, S. T. \& Ryan, T. E. Skeletal Muscle Mitochondrial Dysfunction and Oxidative Stress in Peripheral Arterial Disease: A Unifying Mechanism and Therapeutic Target. Antioxidants 9, 2020; p. 1304.

2. Tarnopolsky, M. A. \& Raha, S. Mitochondrial myopathies: diagnosis, exercise intolerance, and treatment options. Medicine and science in sports and exercise 37, 2005; pp. 2086-2093.

3. Sahebkar, A. et al. Pathophysiological mechanisms of statin-associated myopathies: possible role of the ubiquitin-proteasome system. Journal of Cachexia, Sarcopenia and Muscle 11, 2020; pp. $1177-1186$.

4. Zhang, X. et al. Involvement of reductive stress in the cardiomyopathy in transgenic mice with cardiac-specific overexpression of heat shock protein 27. Hypertension 55, 2010; pp. 1412-1417.

5. Endo, I. et al. Deletion of Vitamin D Receptor Gene in Mice Results in Abnormal Skeletal Muscle Development with Deregulated Expression of Myoregulatory Transcription Factors. Endocrinology 144, 2003; pp. 5138-5144; 10.1210/en.2003-0502 .

6. Couillard, A. Maltais F, Saey D, Debigaré R, Michaud A, Koechlin C, LeBlanc P, Préfaut C. Exercise-induced quadriceps oxidative stress and peripheral muscle dysfunction in patients with chronic obstrucyive pulmonary disease. Am J Respir Crit Care Med 167, 2003; pp. 1664-1669.

7. Thompson, P. D., Clarkson, P. \& Karas, R. H. Statin-associated myopathy. Jama 289, 2003; pp. 1681-1690.

8. Fernandez-Sola, J. et al. Patients with chronic glucocorticoid treatment develop changes in muscle glycogen metabolism. Journal of the neurological sciences 117, 1993; pp. 103-106.
9. Liu, J. et al. Mitochondrial Dysfunction Launches Dexamethasone-Induced Skeletal Muscle Atrophy via AMPK/FOXO3 Signaling. Molecular Pharmaceutics 13, 2016; pp. 73-84; 10.1021/acs.molpharmaceut.5b00516.

10. Chen, C. CiteSpace II: Detecting and visualizing emerging trends and transient patterns in scientific literature. Journal of the American Society for information Science and Technology 57, 2006; pp. 359-377.

11. Chen, C., Hu, Z., Liu, S. \& Tseng, H. Emerging trends in regenerative medicine: a scientometric analysis in CiteSpace. Expert opinion on biological therapy 12, 2012; pp. 593-608.

12. Ochala, J. \& Sun, Y.-B. Novel myosin-based therapies for congenital cardiac and skeletal myopathies. Journal of Medical Genetics 53, 2016; pp. 651-654; 10.1136/jmedgenet-2016-103881.

13. Salem, R. O., Laposata, M., Rajendram, R., Cluette-Brown, J. E. \& Preedy, V. R. THE TOTAL BODY MASS OF FATTY ACID ETHYL ESTERS IN SKELETAL MUSCLES FOLLOWING ETHANOL EXPOSURE GREATLY EXCEEDS THAT FOUND IN THE LIVER AND THE HEART. Alcohol and Alcoholism 41, 2006; pp. 598-603; 10.1093/alcalc/ag1069.

14. Adachi, J. et al. 7alpha- and 7beta-Hydroperoxycholest-5-en3beta-ol in Muscle as Indices of Oxidative Stress: Response to Ethanol Dosage in Rats. Alcoholism: Clinical and Experimental Research 24, 2000; pp. 675-681; 10.1111/j.1530-0277. 2000.tb02039.x.

15. Lang, C. H., Frost, R. A., Svanberg, E. \& Vary, T. C. IGFI/IGFBP-3 ameliorates alterations in protein synthesis, eIF4E availability, and myostatin in alcohol-fed rats. American Journal of Physiology-Endocrinology and Metabolism 286, 2004; pp. E916-E926; 10.1152/ajpendo.00554.2003.

16. Fernandez-Sola, J. et al. Muscle Antioxidant Status in Chronic Alcoholism. Alcoholism: Clinical and Experimental Research 26, 2002; pp. 1858-1862; 10.1111/j.1530-0277.2002.tb02493.x.

17. Nowak, K. J., Ravenscroft, G. \& Laing, N. G. Skeletal muscle $\alpha$ actin diseases (actinopathies): pathology and mechanisms. Acta Neuropathologica 125, 2013; pp. 19-32; 10.1007/s00401-0121019-z.

18. Gomes, M. J. et al. Beneficial Effects of Physical Exercise on Functional Capacity and Skeletal Muscle Oxidative Stress in Rats with Aortic Stenosis-Induced Heart Failure. Oxidative Medicine and Cellular Longevity 2016, pp. 1-12; 10.1155/2016/8695716.

19. Preedy, V. R. et al. Alcoholic skeletal muscle myopathy: definitions, features, contribution of neuropathy, impact and diagnosis. European Journal of Neurology 8, 2001; pp. 677-687; 10.1046/j.1468-1331.2001.00303.x.

20. Laufs, U. et al. Treatment Options for Statin-Associated Muscle Symptoms. Deutsches Aerzteblatt Online, 2015; 10.3238/ arztebl.2015.0748.

21. Gomes, M. J. et al. Skeletal muscle aging: influence of oxidative stress and physical exercise. Oncotarget 8, 2017; pp. 2042820440; 10.18632/oncotarget.14670.

22. Gavazzi, A., Maria, R. de, Parolini, M. \& Porcu, M. Alcohol abuse and dilated cardiomyopathy in men. The American Journal of Cardiology 85, 2000; pp. 1114-1118; 10.1016/S00029149(00)00706-2.

23. Glerup, H. et al. Hypovitaminosis D Myopathy Without Biochemical Signs of Osteomalacic Bone Involvement. Calcified Tissue International 66, 2000; pp. 419-424; 10.1007/s002230010085.

24. Moßhammer, D., Schaeffeler, E., Schwab, M. \& Mörike, K. Mechanisms and assessment of statin-related muscular adverse effects: Statin-related myopathy. British Journal of Clinical Pharmacology 78, 2014; pp. 454-466; 10.1111/bcp.12360.

25. Oshima, Y., Kuroda, Y., Kunishige, M., Matsumoto, T. \& Mitsui, T. Oxidative stress-associated mitochondrial dysfunction in corticosteroid-treated muscle cells. Muscle \& Nerve 30, 2004; pp. 4954; 10.1002/mus.20036.

26. Wajner, M. \& Amaral, A. U. Mitochondrial dysfunction in fatty acid oxidation disorders: insights from human and animal studies. Bioscience Reports 36, 2016; p. e00281; 10.1042/ BSR20150240.

27. 水溶性富勒烯纳米粒子抗氧化活性研究及其肿瘤靶向给药系 统的构建. 硕士. 宜春学院. [Zhou, X. Studies on antioxidant activity of water-soluble fullerene nanoparticles and their construction as tumor targeting drug Studies on antioxidant activity of water-soluble fullerene nanoparticles and their construction as tumor targeting drug, 2020] [in Chinese].

28. Jia, L., Hao, S.-L. \& Yang, W.-X. Nanoparticles induce autophagy via mTOR pathway inhibition and reactive oxygen species 
generation. Nanomedicine 15, 2020; pp. 1419-1435; 10.2217/nnm-2019-0387.

29. Afeseh Ngwa, H. et al. Manganese nanoparticle activates mitochondrial dependent apoptotic signaling and autophagy in dopaminergic neuronal cells. Toxicology and Applied Pharmacology 256, 2011; pp. 227-240; 10.1016/j.taap.2011.07.018.

30. Manzo-Avalos, S. \& Saavedra-Molina, A. Cellular and mito- chondrial effects of alcohol consumption. International journal of environmental research and public health 7, 2010; pp. 4281-4304.

31. Bouitbir, J., Sanvee, G. M., Panajatovic, M. V., Singh, F. \& Krähenbühl, S. Mechanisms of statin-associated skeletal muscleassociated symptoms. Pharmacological research 154, 2010; 104201 . 